\title{
Phosphoinositid signal pathway mediate neurite outgrowth in PC12 cells by staurosporine
}

\author{
Zhaleh $\mathrm{H}^{1,2}$, Azadbakht $\mathrm{M}^{1}$, Bidmeshki Pour $\mathrm{A}^{1}$ \\ Department of Biology, Faculty of Science, Razi University, Kermanshah, Iran. hossain_jale@yahoo.com
}

\begin{abstract}
Objectives: In previous studies, we showed that staurosporine uses intracellular calcium ions to affect cell death in PC12 cells. The bulk release of intracellular excessive $\mathrm{Ca}^{2+}$ from intracellular sources into cytosol contributes to neuronal apoptotic events, which in turn results in neuronal cell death. However, the mechanisms of $\mathrm{Ca}^{2+}$-induced neuronal cell death or neurite elongation is still unclear. Therefore, we investigated the relation between phosphoinositid signal pathway, intracellular calcium, and reactive oxygen species on one hand, with staurosporine-induced neurite outgrowth in PC12 cells on the other.

Results: The inhibition of phospholipase C or IP3 receptor antagonist or phosphoinositid signal transduction antagonist produced cell death and suppressed neurite outgrowth by staurosporine in PC12 cells. The inhibition of these enzymes and pathway results in an increase in intracellular $\mathrm{Ca}^{2+}$ although subsequent hydroxyl radical $(\cdot \mathrm{OH})$ production began after inhibitors exposure. $\cdot \mathrm{OH}$ production was significantly attenuated in inhibitor supplemented medium treatment, and it was dependent on the intracellular $\mathrm{Ca}^{2+}$ concentration. These data indicate that staurosporine activates phosphoinositid signal pathway while endoplasmic $\mathrm{Ca}^{2+}$, and subsequent - OH production are critical events in staurosporine-induced neurite outgrowth in PC12 cells.

Conclusion: We conclude that the fact that staurosporine mobilizes ${ }^{\mathrm{Ca} 2+}$, probably via activating the subcellular compartment, is responsible for staurosporine-induced (Ca2+]i increase during neurite outgrowth in PC12 cells (Fig. 7, Ref. 30). Text in PDF www.elis.sk.

Key words: endoplasmic reticulum, neurite outgrowth, staurosporine, PC12 cells.
\end{abstract}

Staurosporine, a broad spectrum protein kinase inhibitor (1, $2)$, has been used to induce cell death in a wide range of cell types $(3,4)$, or neuronal differentiation at 50-350 nM concentration (5). While the exact mechanism responsible for staurosporine-induced neurite outgrowth is unknown, the exact mechanism responsible for staurosporine-induced cell death is known. Several authors have shown that the exact mechanism responsible for staurosporine-induced cell death in treated cells depends on calcium ions, but several controversial reports exist about the effects of staurosporine on extra or intracellular calcium sources on treated cells of various types. For example, it has been shown that staurosporine induces cell death by increasing cytoplasmic $\mathrm{Ca}^{2+}$ concentration, which in turn is responsible for releasing mitochondrial cytochrome $\mathrm{C}$, caspase-3 activation (6), intracellular ROS accumulation (7-9), increase in $\left(\mathrm{Ca}^{2+}\right)_{\mathrm{i}}(9)$ and cell death in various cell types (e.g. PC12 cells) $(9,10)$.

On the other hand, it has been shown that staurosporine dependent on concentration does not directly release intracellular$\mathrm{Ca}^{2+}$ stores (11). We reported previously that staurosporine could induce neurite outgrowth in PC12 cells and that this apoptosis

${ }^{1}$ Department of Biology, Faculty of Science, Razi University, Kermanshah, Iran, and ${ }^{2}$ Department of Chemical Biotechnology Engineering, Science and Research Branch, Islamic Azad University, Kermanshah, Iran

Address for correspondence: A. Bidmeshki Pour, Department of Biology, Faculty of Science, Razi University, Postal Code: 6714967346, Kermanshah, Iran.

Phone: +98.8314274545 , Fax: +98.8314274545 can be blocked by reducing extracellular calcium stores (12). In contrast, present data suggest that staurosporine can induce apoptosis in cultured cortical neurons and that this apoptosis can be blocked by raising intracellular $\mathrm{Ca}^{2+}(9)$. Previous studies showed that local and global elevations in the cytosolic $\mathrm{Ca}^{2+}$ level are achieved by ion release from intracellular stores and by influx from the extracellular milieu (13). The major intracellular $\mathrm{Ca}^{2+}$ store is the endoplasmic reticulum (ER). $\mathrm{Ca}^{2+}$ release is regulated by transmembrane channels on the $\mathrm{Ca}^{2+}$ store membrane that are formed by tetramers of inositol $(1,4,5)$-triphosphate receptor (IP3R) proteins (14-16). The bulk of IP3R channels mediate the release of $\mathrm{Ca}^{2+}$ from ER, the emptying of which signals $\mathrm{Ca}^{2+}$ influx $(14,16-18)$.

Further, the authors show that ER and mitochondria $\mathrm{Ca} 2+$ stores were shown to be generating inositol 1,4,5-trisphosphate (IP3) and causing the release of $\mathrm{Ca}^{2+}$ from ER which would also promote mitochondrial $\mathrm{Ca}^{2+}$ increase (19-21). In this study, we try to explain the possible role of $\mathrm{Ca}^{2+}$ and $\mathrm{ROS}$ in staurosporineinduced neurite outgrowth in PC12 cells.

\section{Materials and methods}

\section{Cell culture}

Cultures were grown in a $40-\mathrm{cm}^{2}$ tissue culture flask in RPMI culture medium supplemented with $10 \%$ heat-inactivated horse serum and $5 \% \mathrm{FBS}, 1 \% \mathrm{NEAA}, 2 \mathrm{mM}$ L-glutamine, and $100 \mathrm{IU} / \mathrm{ml}$ penicillin and $100 \mu \mathrm{g} / \mathrm{ml}$ streptomycin. To obtain neuronally dif- 
ferentiated PC12 cultures, cells were grown on collagen-coated plates $(10 \mu \mathrm{g} / \mathrm{ml})$ supplemented with $2 \%$ heat-inactivated horse serum, $10 \% \mathrm{FBS}$, and $214 \mathrm{nM}$ staurosporine for $24 \mathrm{~h}$. Cultures were maintained at $37^{\circ} \mathrm{C}$ in a humidified, $5 \% \mathrm{CO}_{2}$ incubator. In differentiated PC12 cells, all experiments were performed in the presence of staurosporine to prevent the possibility of extracellular and intracellular $\mathrm{Ca}^{2+}$-deprived inhibition of neurite outgrowth and induction of cell death signaling pathways.

\section{Cell treatment}

One day after plating the PC12 cells, the cells were washed with phosphate buffer saline (PBS) with $\mathrm{pH}$ 7.4. In order to inhibit phospholipase $\mathrm{C}$, IP3 receptors, and phosphoinositid signal pathway, the cells were preincubated with added $10 \mu \mathrm{M}$ U73122 for $30 \mathrm{~min}$ (treatment 1), $50 \mu \mathrm{M}$ heparin for $30 \mathrm{~min}$ (treatment 2) and $10 \mathrm{mM}$ neomycin sulfate for $30 \mathrm{~min}$ (treatment 3 ). In our experiment, we combined all inhibitors for complete compartments of signal pathway inhibition (treatment4). Then, the cells were cultured in differentiation medium containing complete culture medium supplemented with $214 \mathrm{nM}$ staurosporine for $24 \mathrm{~h}$. PC12 cells cultured in differentiation medium without inhibitor preincubation serve as a control group. The cells were placed in the incubator at $37^{\circ} \mathrm{C}$ with $5 \% \mathrm{CO}_{2}$.

\section{Measurement of cytotoxicity}

Cell cytotoxicity was measured with LDH-cytoxicity Detection Kit (Roche., Germany). In each treatment, the percentage of cytotoxicity was measured according to the protocol of the company, and the colorimetery of LDH activity was measured by calculating the absorbance of samples at 490 or $492 \mathrm{~nm}$. The reference wavelength should be more than $600 \mathrm{~nm}$.

\section{Quantification of cell death incidence}

Hoechst / PI nuclear staining was carried out as previously described (12). Briefly, cells were plated in 24-well culture plates with $10^{4}$ cells $/ \mathrm{mLdensity} \mathrm{for} 12 \mathrm{~h}$. Then cells were pretreated with different treatment mediums for certain time. These were grown for a range of times in differentiation medium $(6,12$ and $24 \mathrm{~h})$. Then the cells were incubated for $15 \mathrm{~min}$ at $37^{\circ} \mathrm{C}$ with Hoechst 33342 dye (10 mg/ml in PBS), and washed twice in PBS. PI (50 $\mathrm{mg} / \mathrm{ml}$ in PBS) was added just before microscopy. Cells were visualized using an inverted-florescence microscope (Olympus IX-71, Japan). The apoptotic index was calculated by the fraction of numbers of apoptotic cells on the total cell count in 100 ( $\sim 300$ cells), respectively. All experiments were replicated independently at least 3 times. Within each experiment, we replicated each condition 4 times.

\section{Measurement of neurite length, fraction of cell differentiation}

Measurement of neurite length and fraction of cell differentiation were carried out as reported by recent studies $(5,23)$. Cells were plated at a density of $2 \times 10^{4}$ cells/well on 24 -well tissue culture plates overnight. The culture media were replaced with different treatment media. After $5 \mathrm{~h}$, the cultured differentiated PC12 cells were fixed with $4 \% \mathrm{w} / \mathrm{v}$ Para formaldehyde. Extracellular $\mathrm{Ca}^{2+}$ were measured with a calcium ion atomic absorption method. Total neurite length (TNL) and the fraction of neurite-bearing cells $(f \%)$ was evaluated under an inverted microscope. TNL: Length of the largest neurite on individual PC12 cell was measured. More than 100 cells were analyzed in each well. $\mathrm{f} \%=\mathrm{n}_{+} / \mathrm{n}_{\mathrm{T}} ; \mathrm{n}_{+}$and $\mathrm{n}_{\mathrm{T}}$ are the numbers of neurite-bearing cells with at last one neurite longer than the cell body diameter, and total count ( $\sim 300$ cells $)$. Each experiment was repeated five times.

\section{Measurement of $\left(\mathrm{Ca}^{2+}\right) \mathrm{c}$ and $\left(\mathrm{Ca}^{2+}\right) \mathrm{m}$}

Measurement of cytosolic $\left(\mathrm{Ca}^{2+}\right) \mathrm{c}$ and mitochondrial $\left(\mathrm{Ca}^{2+}\right)$ $\mathrm{m}$ calcium concentration were carried out as reported by recent studies (6). For $\left(\mathrm{Ca}^{2+}\right) \mathrm{c}$ measurements, $\mathrm{PC} 12$ cells were loaded with $4 \mu \mathrm{M}$ fura- $2 \mathrm{AM}$ at $37{ }^{\circ} \mathrm{C}$ in a $5 \% \mathrm{CO}_{2}$ incubator for 20 min in $\mathrm{HCO}_{3}^{-}$- buffered solution containing $(110 \mathrm{mM} \mathrm{NaCl}$, $4.5 \mathrm{mM} \mathrm{KCl}, 1 \mathrm{mM} \mathrm{NaH} \mathrm{PO}_{4}, 1 \mathrm{mM} \mathrm{MgSO}_{4}, 1.5 \mathrm{mM} \mathrm{CaCl}_{2}, 5$ $\mathrm{mM}$ HEPES-Na, $5 \mathrm{mM}$ HEPES free acid, $25 \mathrm{mM} \mathrm{NaHCO}_{3}$ and $10 \mathrm{mM}$ D-glucose (pH 7.4)). Cells were then rinsed twice and incubated in the $\mathrm{HCO}_{3}{ }^{-}$- buffered solution for at least $20 \mathrm{~min}$ before use, while cells were superfused at a constant perfusion rate of $2 \mathrm{ml} / \mathrm{min}$ with the $\mathrm{HCO}_{3}{ }^{-}$-buffered solution equilibrated with 95 $\% \mathrm{O}_{2}$ and $5 \% \mathrm{CO}_{2}$ to maintain $\mathrm{pH}$ of 7.4. All experiments were performed at $37{ }^{\circ} \mathrm{C}$. The excitation wavelength was alternated between 340 and $380 \mathrm{~nm}$, and the emission fluorescence was recorded at $510 \mathrm{~nm} .\left(\mathrm{Ca}^{2+}\right) \mathrm{c}$ values were calculated using the equation described by Grynkiewicz (24). Relative $\left(\mathrm{Ca}^{2+}\right) \mathrm{m}$ was measured with the fluorescent probe rhod 2-AM following methods described previously (25).

\section{Measurement of antioxidant enzyme activities}

Antioxidant enzyme activities and protein damage assay were carried out as previously described (26). Briefly, in order to visualize intracellular ROS and examine the effect of extracellular $\mathrm{Ca}^{2+}$ on ROS generation, cells were incubated with $214 \mathrm{nM}$ staurosporine for $6 \mathrm{~h}$, then washed three times with Krebs-Ringer-Hepes (KRH) buffer (136 mM NaCl, $4.7 \mathrm{mM} \mathrm{KCl}, 1.25 \mathrm{mM} \mathrm{CaCl}_{2}, 1.25$ $\mathrm{mM} \mathrm{MgSO}_{4}, 20$ mM Hepes, pH 7.4); $1 \mu \mathrm{M}$ APF in KRH buffer was added, and cells were incubated for $1 \mathrm{~h}$ at $37^{\circ} \mathrm{C}$. Fluorescence (Ex. $490 \mathrm{~nm}$ and Em. $525 \mathrm{~nm}$ ) was visualized using a fluorescence microscope.

\section{Statistical analysis}

Results are presented as the means $\pm \mathrm{SD}$ of three or four independent experiments. When comparing two groups, unpaired Student's t-test was used to address the differences.

p-values less than 0.05 were considered significant.

\section{Results}

After 6h, cells in control group exhibited neuron morphology with long neurite outgrowth (Fig. 1). TNL control group was determined as $182 \pm 0.85 \mu \mathrm{m}$, respectively, but in treatments $1-4$ the corresponding values decreased (Fig. 2$)(\mathrm{p}<0.05)$. In addition to an increase in the length of neurite in control group, the neuronal network was seen to be producing in limited environment (Fig. 1). 
After $6 \mathrm{~h}$, the fraction of cell differentiation ( $\mathrm{f} \%$ ) for control group was $100 \%$, but in treatments $1-4$ were it decreased $(96 \%, 71 \%$, $67 \%$ and $54 \%$, respectively) (p<0.05) (Fig. 3). After $24 \mathrm{~h}$, the percentage of cell differentiation in treatments 1-4 compared with control group ( $98 \%$ ) were decreased $(\mathrm{p}<0.05)$. The documented percentages of cell differentiation after $24 \mathrm{~h}$ for treatments $1-4$ were $81 \%, 53 \%, 52 \%$ and $41 \%$, respectively (p<0.05) (Fig. 3). After $6 \mathrm{~h}$, the percentage of cell death for control group was $16 \%$, but in treatments $1-4$ it increased $(26 \%, 33 \%, 38 \%$ and $42 \%$, respectively) $(\mathrm{p}<0.05)$ (Fig. 4). After $24 \mathrm{~h}$, the percentages of cell death in treatments $1-4$ compared with control group (28\%) were increased $(\mathrm{p}<0.05)$. while the documented percentages of cell death after $24 \mathrm{~h}$ for treatments $1-4$ were $46 \%, 52 \%, 57 \%$ and $62 \%$, respectively ( $\mathrm{p}<0.05)$ (Fig. 4).

At the starting point of experiments, the percentage of cell cytotoxicity for PC12 cells were constant, namely $98 \%$ and $99 \%$, respectively (Fig. 5). After 24 h, The percentage of cytotoxicity
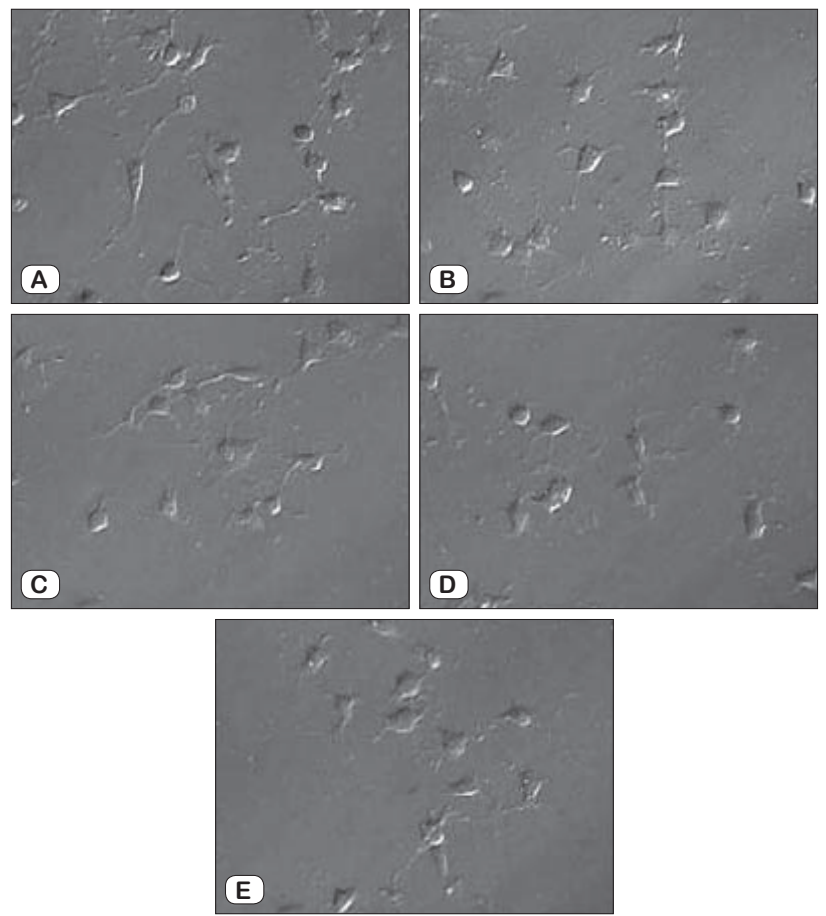

Fig. 1. PC12 cell differentiation induced by different treatment media. PC12 cells were grown on tissue culture plate in $10 \% \mathrm{FBS}-\mathrm{RPMI}$ 1640 containing $214 \mathrm{nM}$ staurosporine (Control group) at presence of different inhibitors (treatments 1-4) for $24 \mathrm{~h}$. After $6 \mathrm{~h}$, in control group, PC12 cells exhibited a neuron-like morphology with long neurite outgrowth with formed neuronal network (A). After 24 h, PC12 cells in treatments 1-4 did not exhibit an extent neuron-like morphology or neurite-like structure (B-E). After 24 h, treatments 1-4, compared with control group significantly suppressed the neurite in PC12 cells (B-E).

Control group: incubation with $214 \mathrm{nM}$ staurosporine, (A): treatment 1: $10 \mu \mathrm{M}$ U73122, $30 \mathrm{~min},(\mathrm{~B})$ : treatment 2: $50 \mu \mathrm{M}$ heparine, $30 \mathrm{~min}$, (C): treatment 3: $10 \mathrm{mM}$ neomycine sulfate, (D): treatment 4: combination of all inhibitors. $\square 6 \mathrm{~h} \square 12 \mathrm{~h} \square 24 \mathrm{~h}$

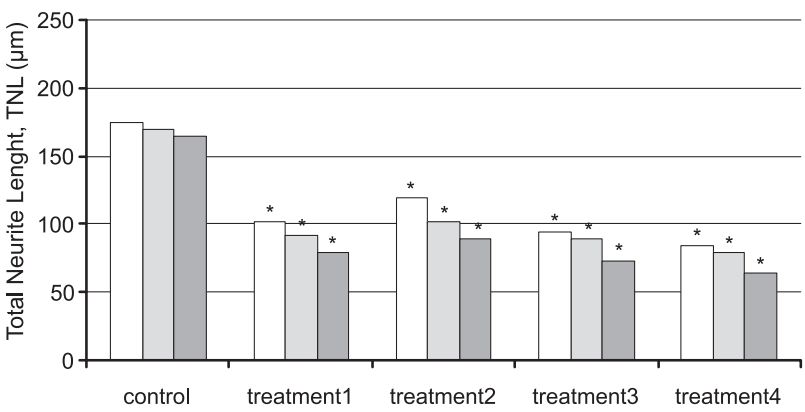

Fig. 2. Neurite length of PC12 cells treated in culture media containing $214 \mathrm{nM}$ staurosporine at different treatment media $(\mu \mathrm{m})$. PC12 cells were grown on tissue culture plate in $10 \%$ FBS - RPMI 1640 containing $214 \mathrm{nM}$ staurosporine (Control group) at presence of different inhibitors (treatments 1-4) for $6 \mathrm{~h}$. After $24 \mathrm{~h}$, treatments 1-4, compared with control group significantly suppressed the neurite in PC12 cells $(p<0.05)$. Control group: incubation with $214 \mathrm{nM}$ staurosporine, treatment 1: 10 $\mu \mathrm{M}$ U73122, $30 \mathrm{~min}$, treatment 2: $50 \mu \mathrm{M}$ heparine, $30 \mathrm{~min}$, treatment 3: $10 \mathrm{mM}$ neomycine sulfate, treatment 4 : combination of all inhibitors. All data represented by mean \pm standard.* $p<0.05$ as evaluated by paired ANOVA.

\section{$\square 6 \mathrm{~h} \square 12 \mathrm{~h} \square 24 \mathrm{~h}$}

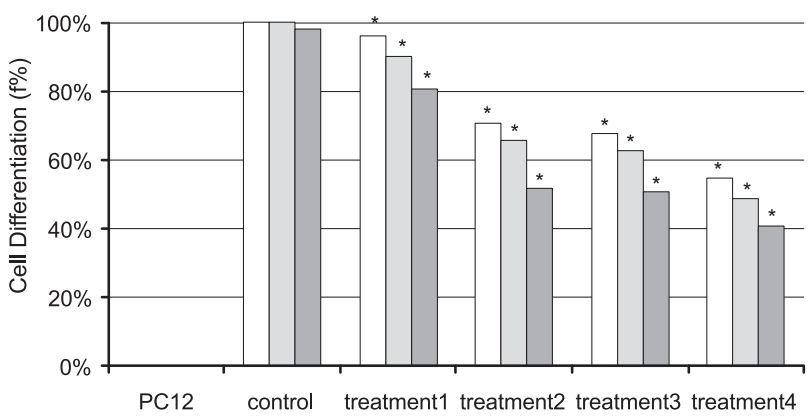

Fig. 3. The percentages of fraction of cell differentiation during PC12 cell differentiation induced by different treatment media. The fraction of cell differentiation for treatments 1-4 compared with control group was decreased $(p<0.05)$. Control group: incubation with $214 \mathrm{nM}$ staurosporine, treatment 1: $10 \mu \mathrm{M}$ U73122, $30 \mathrm{~min}$, treatment 2: $50 \mu \mathrm{M}$ heparine, $30 \mathrm{~min}$, treatment 3: $10 \mathrm{mM}$ neomycine sulfate, treatment 4: combination of all inhibitors.

All data represented by mean \pm standard. ${ }^{*} \mathbf{p}<0.05$ as evaluated by paired ANOVA.

in control group compared with PC12 cells (6\%) increased up to $21 \%$, but in treatments $1-4$ compared with PC12 cells and control group it was significantly increased $(\mathrm{p}<0.05)$ (Fig. 5).

Previous studies indicate that uncontrolled cytosolic or mitochondrial $\mathrm{Ca}^{2+}$ overload mediates staurosporine-induced cell death in neuronal cells $(8,9)$. In order to determine whether the inhibition of phosphoinositid signal pathway is essential for initiating staurosporine-activated cell death signaling, we analyzed $\left(\mathrm{Ca}^{2+}\right) \mathrm{c}$ and $\left(\mathrm{Ca}^{2+}\right) \mathrm{m}$ in treated cells.

Exposure of PC12 cells to $214 \mathrm{nM}$ staurosporine in the absence of inhibitors had little effect on $\left(\mathrm{Ca}^{2+}\right)$. In treatments $1-4$, 
$\square 6 \mathrm{~h} \square 12 \mathrm{~h} \square 24 \mathrm{~h}$

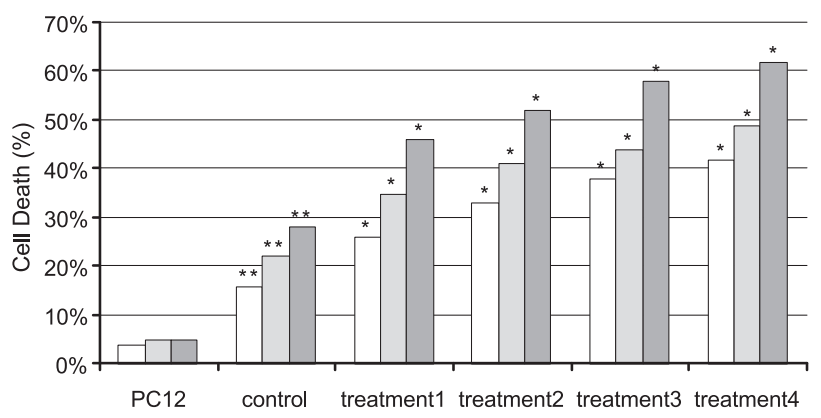

Fig. 4. LDH activities during PC12 cell differentiation induced by different treatment media for $24 \mathrm{~h}$. The percentage of cell cytotoxicity in treatments 1-4 compared with was decreased $(\mathbf{p}<0.05)$. Control group: incubation with $214 \mathrm{nM}$ staurosporine, treatment 1: $10 \mu \mathrm{M} \mathrm{U73122,30}$ min, treatment 2: $50 \mu \mathrm{M}$ heparine, $30 \mathrm{~min}$, treatment 3: $10 \mathrm{mM}$ neomycine sulfate, treatment 4: combination of all inhibitors. All data represented by mean \pm standard.* $p<0.05$ as evaluated by paired ANOVA.

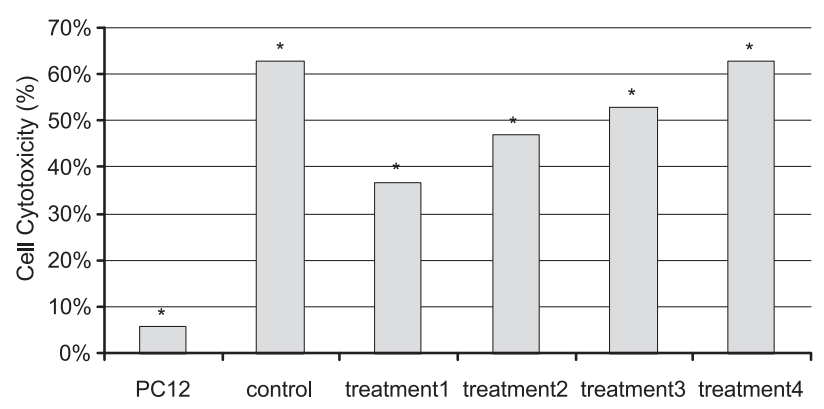

Fig. 5. The percentage of cell death during PC12 cell differentiation induced by different treatment media for $24 \mathrm{~h}$. The percentage of cell death in treatments 1-4 compared with was increased $(p<0.05)$. Control group: incubation with $214 \mathrm{nM}$ staurosporine, treatment 1: $10 \mu \mathrm{M}$ U73122, 30 min, treatment 2: $50 \mu \mathrm{M}$ heparine, $30 \mathrm{~min}$, treatment 3: $10 \mathrm{mM}$ neomycine sulfate, treatment 4: combination of all inhibitors. All data represented by mean \pm standard. ${ }^{*} \mathbf{p}<0.05$ as evaluated by paired ANOVA.

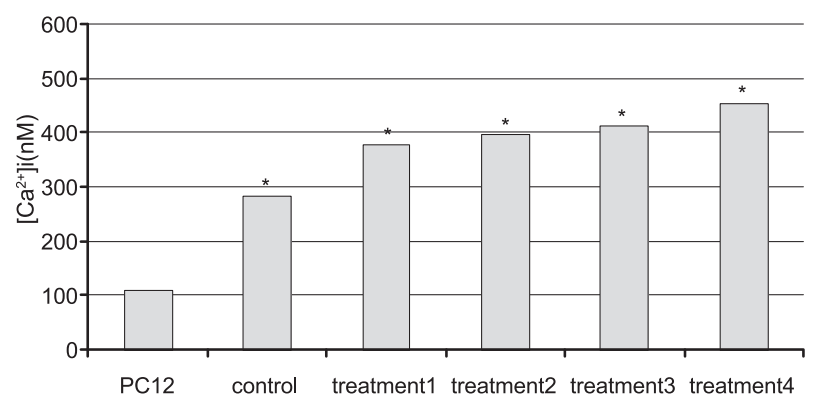

Fig. 6. Determination of $\left(\mathrm{Ca}^{2+}\right) \mathrm{i}$ in staurosporine (STS)-treated PC12 cells for $6 \mathrm{~h}(\mathrm{nM})$. PC12 cells were incubated for $6 \mathrm{~h}$ in the absence (PC12 cells) or in the presence (control cells) of $214 \mathrm{nM} \mathrm{STS}$ at the presence of different inhibitors (treatments groups). Control group: incubation with $214 \mathrm{nM}$ staurosporine, treatment 1: $10 \mu \mathrm{M}$ U73122, $30 \mathrm{~min}$, treatment 2: $50 \mu \mathrm{M}$ heparine, $30 \mathrm{~min}$, treatment 3: $10 \mathrm{mM}$ neomycine sulfate, treatment 4 : combination of all inhibitors. The results are expressed as the mean \pm SEM of 4-6 experiments, run in duplicate. Statistical significance: * $\mathbf{p}<0.005$ as compared to control cells. the $\left(\mathrm{Ca}^{2+}\right) \mathrm{c}$ were increased compared to control group and $\mathrm{PC} 12$ cells $(p<0.05)$ (Fig. 6). Since staurosporine caused an early and sustained increase in $\left(\mathrm{Ca}^{2+}\right) \mathrm{c}$ in treatment $1-4$, we speculated that $\mathrm{Ca}^{2+}$ might have accumulated in mitochondria. In this section, we assessed changes in $\left(\mathrm{Ca}^{2+}\right) \mathrm{m}$ microscopically in living cells loaded with the mitochondrial $\mathrm{Ca}^{2+}$ indicator Rhod 2-AM. Following the treatment inhibitors comparison with control cells, we observed a significant increase in $\left(\mathrm{Ca}^{2+}\right) \mathrm{m}$ (Fig. 6).

Exposure of PC12 cells to $214 \mathrm{nM}$ staurosporine in the absence of inhibitors had little effect on ROS $(\cdot \mathrm{OH})$ generation. In treatments $1-4$, the $(\mathrm{OH})$ generation was increased compared with control group and PC12 cells $(\mathrm{p}<0.05)$ (Fig. 7). It is well shown that overload of cytosolic and mitochondrial $\mathrm{Ca}^{2+}$ causes enhanced accumulation and cytochrome $\mathrm{c}$ release in ROS pathway in treated cells.

\section{Discussion}

In this current study, we investigate the involvement of subcellular compartment which is responsible for the staurosporineinduced neurite outgrowth in PC12 cells. We also used PC12 cells as the best cell model for studying the effect of materials on neurite outgrowth (23). Staurosporine was employed as a strong inducer of neurite outgrowth with inhibition of protein kinases in vitro model. we also try to show that inhibition of PLC, IP3R or phosphoinositid signal pathway could effectively inhibit neurite outgrowth induced by staurosporine and increase cell death and cytotoxicity by increased ROS generation and $\left(\mathrm{Ca}^{2+}\right) \mathrm{i}$ in PC12 cells.

We observed that when cells were preincubated with U73122, which is a specific phospholipase $\mathrm{C}$ antagonist, heparin, which is a specific IP3R antagonist, and neomycin, which is a specific phosphoinositid signal pathway antagonist, they dramatically

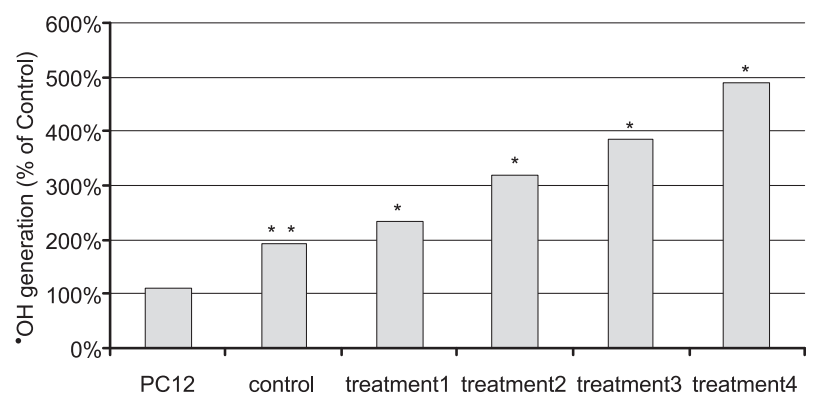

Fig. 7. Effect of antioxidants and reduce agents of endogenous reactive oxygen species (ROS) production on staurosporine (STS)-induced neurite outgrowth for $6 \mathrm{~h}$ (\% control). PC12 cells were incubated for $6 \mathrm{~h}$ in the absence (PC12 cells) or in the presence (control cells) of $214 \mathrm{nM} \mathrm{STS} \mathrm{at}$ the presence of different inhibitors (treatments groups). Control group: incubation with $214 \mathrm{nM}$ staurosporine, treatment 1: $10 \mu \mathrm{M}$ U73122, 30 min, treatment 2: $50 \mu \mathrm{M}$ heparine, $30 \mathrm{~min}$, treatment 3: $10 \mathrm{mM}$ neomycine sulfate, treatment 4: combination of all inhibitors. The results are expressed as the mean \pm SEM of 4-6 independent experiments, run in duplicate. Statistical significance: * $\mathbf{p}<\mathbf{0 . 0 0 5}$ as compared to control cells. 
suppressed the neurite outgrowth and increased cell death and cytotoxicity in PC12 cells. It could be suggested that there is a possible involvement of IP3R and PLC $\gamma$ in staurosporine-neurite outgrowth.

The results showed that staurosporine can regulate and decrease the intracellular calcium concentration by activating the phosphoinositid signal pathway. It was demonstrated that neurite outgrowth in PC12 by staurosporine is induced via the $\mathrm{Ca}^{2+}$ signal transduction pathway by the $\mathrm{Ca}^{2+}$ influxes through endoplasmic reticulum channels. On the other hand, recent study showed that staurosporine leads to intracellular calcium overload, which induces apoptosis in PC12 cells (6). In the percent study, we showed that inhibition of IP3R and PLC $\gamma$ caused a large increase in $\left(\mathrm{Ca}^{2+}\right) \mathrm{c}$, IP3-sensitive $\mathrm{Ca}^{2+}$ store, and ROS generation in PC12 cells. This result indicates that IP3-sensitive ER compartments are responsible for staurosporine-induced $\left(\mathrm{Ca}^{2+}\right) \mathrm{c}$ increase in PC12 cells.

We reported previously that staurosporine can induce neurite outgrowth in PC12 cells and that this apoptosis can be blocked by reducing extracellular calcium stores (12). In addition, it is known that cytosolic $\mathrm{Ca}^{2+}$ increase caused by staurosporine, which in turn mobilizes $\mathrm{Ca}^{2+}$ from different sources, might cause apoptosis in astrocytes (27).

In accordance with these results, we detected inhibition of IP3R and PLC $\gamma$, as well as increase in intracellular $\mathrm{Ca}^{2+}$ (mitochondrial and cytosolic), which then activates ROS ( $\mathrm{OH}$ generation) signal pathway (Figs 6 and 7).

In this work, the inhibition of IP3R and PLC $\gamma$ significantly increased the production of intracellular peroxides, while increasing the intracellular $\mathrm{Ca}^{2+}$ (mitochondrial and cytosolic) triggered by staurosporine in PC12 cells. Moreover, the results strongly suggest that ROS generation contributes to this apoptotic and neurite outgrowth suppression mechanism.

On the other side, previous studies demonstrated that intracellular ROS production induced by staurosporine can result from interrupted mitochondrial electron flow as a consequence of cytochrome $c$ release $(28,29)$. However, endoplasmic reticulum has not been investigated as a source of $\mathrm{Ca}^{2+}$.

In this study we showed that inhibition of IP3R and PLC $\gamma$ caused endogenous ROS production in staurosporine-induced neurite outgrowth resulting in an increase in cell death in PC12 cells. However, authors showed that ROS can interfere with the mechanisms responsible for intracellular $\mathrm{Ca}^{2+}$ regulation (30) and staurosporine was previously demonstrated to induce a rise in intracellular $\mathrm{Ca}^{2+}(9)$.

In the present study, we show that inhibition of IP3R and PLC $\gamma$ were shown to attenuate the rise in intracellular calcium triggered by staurosporine thus strongly suggesting that ROS generation can potentiate the observed intracellular calcium overload.

\section{References}

1. Tamaoki T, Nomoto H, Takahashi I, Kato Y, Morimoto M, Tomita F. Staurosporine, a potent inhibitor of phospholipid/ $\mathrm{Ca}^{2+}$-dependent protein kinase. Biochem Biophys Res Comm 1986; 135 (5): 397-402.

2. Nakano H, Kobayashi E, Takahashi I, Tamaoki T, Kuzuu Y, Iba H. Staurosporine inhibits tyrosine-specific protein kinase activity of Rous sarcoma virus transforming protein $\mathrm{p}$ 60. J. Antibiotics 1987; 50 (12): 706-711.

3. Kabir J, Lobo M, Zachary I. Staurosporine induces endothelial cell apoptosis via focal adhesion kinase dephosphorylation and focal adhesion disassembly independent of focal adhesion kinase proteolysis. Biochem J 2002; 367 (6): 45-49.

4. Witasp E, Gustafsson AC, Cotgreave I. Vitamin D fails to prevent serum starvation- or staurosporine-induced apoptosis in human and rat osteosarcoma-derived cell lines. Biochem Biophys Res Commun 2005; 330 (5): 891-896.

5. Rasouly D, Rahamim E, Lester D, Matsuda Y, Lazarovici P. Staurosporine induced neurite outgrowth in PC12 cells is independent of protein kinase C inhibition. Mol Pharmacol 1992; 42 (5): 35-39.

6. Seo SR, Seo JT. Calcium overload is essential for the acceleration of staurosporine-induced cell death following neuronal differentiation in PC12 cells. Exp and Mol Medicine 2009; 41 (9): 269-276.

7. Krohn AJ, Preis E, Prehn JHM. Staurosporine-induced apoptosis of cultured rat hippocampal neurons involves caspase-1 like proteases as upstream initiators and increased production of superoxide as a main downstream effectors. J. Neurosci 1998; 18 (8): 8186-8190.

8. Prehn JHM, Jorda'n J, Ghadge GD, Preis E, Galdino MF, Roos RP, Krieglstein $\mathbf{J}$ et al. $\mathrm{Ca}^{2+}$ and reactive oxygen species in staurosporineinduced neuronal apoptosis. J Neurochem 1997; 685: 1679-1684.

9. Kruman I, Guo O, Mattson MP. Calcium and reactive oxygen species mediate staurosporine-induced mitochondrial dysfunction and apoptosis in PC12 cells. J Neurosci Res 1998; 51 (5): 293-298.

10. Johansson AC, Steen H, Ollinger K. Cathepsin D mediates cytochrome c release and caspase activation in human fibroblast apoptosis induced by staurosporine. Cell Death Differ 2003; 10 (8): 1253-1258.

11. Koh JY, Cotman CW. Programmed cell death: its possible contribution to neurotoxicity mediated by calcium channel antagonists. Brain Res 1992; 587 (7): 233-239.

12. Zhaleh H, Azadbakht M, Bidmeshki Pour A. Effects of extracellular calcium concentration on neurite outgrowth in $\mathrm{PC} 12$ cells by staurosporine. Neuroscience Lett 2011; 498 (9): 1-5.

13. Berridge MJ, Lipp P, Bootman MD. The versatility and universality of calcium signaling. Nat Rev Mol Cell Biol 2000; 1 (9): 11-18.

14. Mikoshiba K. Inositol 1,4,5-triphosphate (IP3): receptors and their role in neuronal cell function. J Neurochem 2006; 97 (11): 1627-1632.

15. Patterson RL, Boehning D, Snyder SH. Inositol 1,4,5-triphosphate receptors as signal integrators. Ann Rev Biochem 2004; 73 (5): 437-442.

16. Vermassen E, Parys JB, Mauger JP. Subcellular distribution of the inositol 1,4,5-triphosphate receptors: functional relevance and molecular determinants. Biol Cell 2004; 96 (7): 3-8.

17. Putney JW, Bird GS. Cytoplasmic calcium oscillations and storeoperated calcium influx. J Physiol 2008; 586 (12): 3055-3059.

18. Semenova SB, Kiselev KI,Mozhaeva GN. Low-conductivity calcium channels in the macrophage plasma membrane: activation by inositol-1,4,5triphosphate. Neurosci Behav Physiol 1999; 29 (9): 339-345. 
203-208

19. Rizzuto R, Pinton P, Carrington W, Fay FS, Fogarty KE, Lifshitz LM, Tuft RA et al. Close contacts with the endoplasmic reticulum as determinants of mitochondrial $\mathrm{Ca}^{2+}$ responses. Science 1998; 280 (5): 1763-1768.

20. Hajnoczky G, Robb-Gaspers LD, Seitz M, Thomas AP. Decoding of cytosolic calcium oscillations in the mitochondria. Cell 1995; 82 (8): 415-421.

21. Jouaville LS, Ichas F, Holmuhamedov EL, Camacho P, Lechleiter JD. Synchronization of calcium waves by mitochondrial substrates in Xenopus laevis oocytes. Nature 1995; 377 (12): 438-343.

22. Rizzuto R, Simpson AW, Brini M, Pozzan T. Rapid changes of mitochondrial $\mathrm{Ca}^{2+}$ revealed by specifically targeted recombinant aequorin. Nature 1992; 358 (9): 325-329.

23. Ronn LC, Ralets I, Hartz BP, Bech M, Berezin A, Berezin V, Moller A et al. A simple procedure for quantification of neurite outgrowth based on stereological principles. J Neurosci Methods 2000; 100 (5): 25-29.

24. Grynkiewicz G, Poenie M, Tsien RY. A new generation of $\mathrm{Ca}^{2+}$ indicators with greatly improved fluorescence properties. J Biol Chem 1985; 260 (8): 3440-3445.
25. Hoth M, Fanger CM, Lewis RS. Mitochondrial regulation of storeoperated calcium signaling in T lymphocytes. J Cell Biol 1997; 137 (12): 633-638.

26. Abe1 S, Ohnishi H, Tsuchiya K, Ishizawa K, Torii M, Kanematsu Y, Kawazoe K et al. Calcium and Reactive Oxygen Species Mediated $\mathrm{Zn}^{2+}$ Induced Apoptosis in PC12 Cells. J Pharmacol Sci 2006; 102 (9): 103-108.

27. Hirata H, Machado LS, Okuno CS, Brasolin A, Lopes GS, Smaili SS. Apoptotic effect of ethanol is potentiated by caffeine-induced calcium release in rat astrocytes. Neurosci Lett 2006; 393 (11): 136-141.

28. Cai J, Jones DP. Superoxide in apoptosis. J Biol Chem 1998; 273 (12): 11401-11407.

29. Cai J, Wallace DC, Zhivotovsky B, Jones DP. Separation of cytochrome c-dependent caspase activation from thiol-disulfide redox change in cells lacking mitochondrial DNA. Free Radic Biol Med 2000; 29 (6): 334-338.

30. Dawson VL, Dawson TM. Free radicals and neuronal cell death. Cell Death Differ 1996; 3 (8): 71-76. 